\title{
Naturalists' Practices and Nature's Empire: Paris and the Platypus, 1815-1833 ${ }^{1}$
}

\author{
Richard W. Burkbardt $7 r^{2}$
}

\begin{abstract}
Among the multiple interactions between governments and museums that were so important for the growth of natural history in the nineteenth century, perhaps none looked more promising at its inception than did the special "school for naturalist voyagers" that was instituted at the Museum of Natural History in Paris in 1819. Proposed initially by the French Minister of the Interior, who also promised to fund the operation, the idea of the school was to train young naturalists who could then be sent off to the far corners of the globe in search of plants, animals, and minerals useful to France and interesting to science. The professors of the Museum were enthusiastic about the Minister's idea. However, aligning the interests of the naturalists at the Museum with those of the French government and a collection of young, aspiring naturalist voyagers was not an entirely straightforward matter. This paper considers the school for naturalist voyagers in the light of France's prior experiences with naturalist voyages (most notably the Baudin expedition to Australia), her most pressing colonial needs in the early years of the Restoration, and the practices of the naturalists of the Paris Museum. The platypus makes an appearance here amidst a contest over the control of specimens. Finally, we consider notions of "the empire of nature" and what resonance such notions might have had at the Paris Museum at the time the school for naturalists was promoted.
\end{abstract}

NAPOLEON'S FALL FROM power in 1814 , reconfirmed by his final defeat in 1815 , had multiple and diverse implications for the naturalists of the Muséum d'Histoire Naturelle in Paris. One of these was that the naturalists would need to establish productive relations with a new French government. A second was that there would soon be representatives of other governments on the Museum's doorstep, calling for the restoration of natural history treasures that France had confiscated from their countries over the previous two decades. A third was that the Museum would have the opportunity to do something it had not been able to do for more than a decade.

\footnotetext{
1 The research for this paper was supported in part by National Science Foundation Grant No. SBR-9601390. Manuscript accepted 1 February 2001.

2 University of Illinois, Urbana-Champaign, Illinois 61820 .
}

Pacific Science (2001), vol. 55, no. 4:327-341

(C) 2001 by University of Hawai'i Press

All rights reserved
With the Napoleonic wars over and the freedom of the seas restored, the Museum would be able to send naturalist voyagers once again to the far corners of the globe.

All these prospects had an obvious bearing on the continued quality of the Museum's collections and the work of the naturalists located there. In this paper, I focus on the first and third of these stories, leaving aside the matter of the negotiations that took place over the possible repatriation of previously confiscated specimens. I address the specific ways in which, in the early years of the Restoration, the National Museum of Natural History in Paris and the French government sought to promote the activities of naturalist voyagers for the benefit of science and France alike.

\section{NATURALISTS, EMPIRE, AND THE EMPIRE OF NATURE}

Scholars in recent years have called attention to the ways in which science has functioned as a tool of empire (Brockway 1979, McKay 1985, Reingold and Rothenberg 1987, Mac- 
Leod and Lewis 1988, MacLeod and Rehbock 1988, 1994, McClellan 1992, MacLeod 1993, 2000, Osborne 1994, Miller and Reill 1996, Drayton 2000). They have examined, among other things, how metropolitan "centers of accumulation" figured in these imperial enterprises (Latour 1987). But they have also noted occasions when, as Marie-Nöelle Bourguet has put it, "the interests of science and the interests of the empire did not go ... at the same pace" (Bourguet 1997:193). And they have likewise found that scientific activities on the periphery at times generated important new insights and practices and were not simply derivative of the theories and plans generated at imperial centers (Grove 1995, and others cited above).

In this paper I consider France's efforts during the Restoration to use natural historical knowledge for the development of her colonies. I also look at the Paris Museum of Natural History as a center of accumulation. One of my main points will be the heterogeneity of interests in play here. The interests of the French government and the Paris $\mathrm{Mu}$ seum intersected in ways that were advantageous to both parties, but these interests were not entirely identical. For that matter, as we shall see, the interests of the naturalists of the Museum were not themselves completely homogeneous. As a window on the respective aspirations of the government and the $\mathrm{Mu}$ seum in this period, I examine a number of overtures that the government made to the Museum between 1817 and 1819, together with the Museum's responses. The highlight of these was the establishment at the Museum in 1819 of a special school for the training of naturalist voyagers. The story of the school for naturalist voyagers remains largely unexplored in the history of science and even in the more specialized history of French naturalist voyages (but see Thésée 1989, Collini and Vannoni 1997, and, most recently, Chambord 1998).

In keeping with the title of the conference session for which this paper was prepared, I also offer some brief remarks on the concept of nature's empire. There is no doubt that the Museum profited from France's efforts to extend France's empire. It is also clear that the
Museum contributed to France's efforts in this regard. As for the circumstances that might have stimulated naturalists to think in terms of nature's empire, I suggest that notions of nature's empire were more likely to crop up in colonial settings than back in Paris. Colonists attempting to reshape local ecologies inevitably had more of an appreciation of nature's resistances to human intervention than did the naturalists of the metropole whose chief concerns were with the control and classification of specimens.

\section{FRENCH NATURALIST VOYAGERS AND THE LESSONS OF THE PACIFIC}

Does the Pacific have a role to play in this story? It does, albeit more as recurrent bit part than as a dominant role. Understanding the natural history of the Pacific was not the top priority of either the French government or the Paris Museum in the years immediately after 1815 . When it came to promoting overseas natural history activities between 1815 and 1820, the French government was above all concerned with activities that would benefit France's colonies, and at that time France had no colonies in the Pacific. As for the Museum's naturalists in that period, they were very interested in the Pacific as a source of specimens, but they were more concerned with the specimens themselves than they were with understanding in detail the places from which the specimens came.

Historians of the Pacific will be quick to recognize that France had a long tradition of voyages of exploration in the Pacific before the Revolution, and that under the Restoration she launched a new series of Pacific voyages, specifically those of Louis de Freycinet on the Uranie (1817-1820), Louis-Isidore Duperrey on the Coquille (1822-1825), and Jules Dumont d'Urville on the Astrolabe (1826-1829) (Dunmore 1969). In these voyages, however, and particularly in that of Freycinet, naturalists of the Museum thought their interests were given little priority. The reason for this is worth our attention.

In the years after Napoleon's fall from 
power, French thinking about future voyages of exploration was inevitably influenced by experiences from the recent past. The primary example to ponder was thus the expedition of Captain Nicolas Baudin to Australia (1800-1804).

Significantly for our story, opinions on the success of the Baudin voyage were quite mixed by the time the second of the expedition's two main ships, le Géographe, returned to France in 1804. From an imperial point of view, the voyage was of limited success. It returned important intelligence on British fortifications and naval deployments, but although it affixed the name "Terre Napoléon" to French maps of a huge area now forming part of South Australia, it failed to establish any clear claims for France to Australian territory. Furthermore, a great many of its officers, crew, and scientific staff had been lost to illness, desertion, or death. Captain Baudin himself had succumbed to tuberculosis at Isle de France in 1803 on the voyage home. On top of this, stories abounded of mismanagement and corruption on the part of the captain. Napoleon is alleged to have remarked, "Captain Baudin did well to die; if he had returned I would have hanged him" (Horner 1988:12).

From the Museum's perspective, however, things looked immensely better. The expedition had brought an enormous haul of natural history specimens back to France. The zoological collections in particular were especially impressive. These numbered over 100,000 specimens, plus some 960 paintings. Among the animals represented were a number of remarkable forms that had only recently become known to Western science. These included the platypus (first described by Shaw in 1799), the wombat (described by Shaw in 1800), dasyures (described by Kerr in 1792 and Shaw in 1800), kangaroos, and more (Bonnemains et al. 1988). Beyond these, there were more than 2500 animal species (most of them invertebrates, but a number of vertebrates as well) never previously described by Western naturalists (Jussieu 1804).

Not only did the Baudin voyage provide the Museum with a wealth of specimens, it provided France with a handful of experienced naturalist voyagers. In the early years of the Restoration, three veterans of the Baudin voyage proved especially valuable when it came to sending the Museum new specimens from abroad. One was the botanist J.-B. Leschenault de la Tour. The other two were the artist-naturalists Charles-Alexandre Lesueur and Jacques Milbert. Former participants in the Baudin expedition did more than send specimens back to Paris, however. They also sent-or in Leschenault's case, delivered - plants and animals from one colonial setting to another. Likewise active in this regard was Baron Pierre-Bernard Milius, the naval commander in charge of bringing le Géographe back to France after Baudin's death. In 1818 Milius was named commandant and administrator for the king at Isle Bourbon. Four years later he was given the equivalent post in French Guiana. His efforts in shipping exotic plants and animals from one part of the world to another were prodigious.

Beyond providing the Museum, the nation, and the colonies with specimens and experienced voyagers, the Baudin expedition also generated a series of lessons that were factored into plans for subsequent voyages. The most consequential of these was the reminder that the interests of naval officers and naturalists did not always coincide with each other. The frictions that developed between Captain Baudin and the zoologist François Péron had been severe. This fact was not lost on Louis de Freycinet, who commanded the small vessel named the Casuarina during the expedition and who later, after Péron's death in 1810, was given the job of completing the official account of the voyage. When in 1817 Freycinet was appointed commander of the Uranie, he elected to have no civilian naturalists on board. Every member of the expedition was to be in the service of the navyand thus directly under his orders. This was a great source of discontent for the naturalists of the Museum. Fortunately, the expedition's physician, René-Constant Quoy, and its surgeon, Paul Gaimard, proved to be enthusiastic and perspicacious observers and collectors, and the Museum ended up profiting from the expedition of the Uranie much more than 
the professors initially anticipated (Geoffroy Saint-Hilaire 1825). Quoy and Gaimard subsequently sailed with Dumont d'Urville on the expedition of the Astrolabe, and the $\mathrm{Mu}$ seum became accustomed to thinking of them as "physician-naturalists." The Museum likewise benefited from the collecting efforts of naval pharmacist voyagers, most notably René-Primevère Lesson and Charles Gaudichaud-Beaupré (Laissus 1981). It remained the case, nonetheless, that in these expeditions naval interests took precedence over the interests of the naturalists.

The Baudin expedition afforded other lessons as well. It reinforced the importance of having trained scientists do the observing, recording, and collecting on a voyage. It testified to the multiple difficulties of transporting specimens from the far corners of the globe back to Paris. In addition, it provided a new example of the tensions that could emerge between the collectors of specimens in the field and the cabinet naturalists back at the Museum who wanted access to the specimens as soon as possible. The professors of the Museum were prepared to recognize, at least in principle, that naturalist voyagers deserved the right to be the first to describe in print the specimens they had collected. However, they grew anxious when Péron and Lesueur took specimens away from the Museum and spent too long writing up their reports. When Péron died in 1810, a host of specimens from the voyage still remained in his apartment. The Museum moved quickly to have the apartment sealed so that no specimens would be lost (Bonnemains 1988).

There was another lesson that might have emerged from the Baudin expedition but that does not seem to have taken adequate hold. During the voyage, the zoologist Péron had recorded with unprecedented care precisely where he had collected his different specimens. This allowed him to note, among other things, how particular species successively gave way to other species as one traveled farther north or south. This caught the attention of the invertebrate zoologist J.-B. Lamarck in particular, who found support in Péron's discoveries for his own ideas about species change. However, Péron's information on the provenance of his specimens seems to have become separated from the specimens themselves as they made their way into the $\mathrm{Mu}$ seum's collections. The potential significance of the biogeographical data Péron had gathered (and, for that matter, of biogeographical data in general) was not exploited at the $\mathrm{Mu}-$ seum at that time (Burkhardt 1997a).

\section{AN EYE TO THE COLONIES, AND SPECIMENS FOR THE MUSEUM}

Let us turn now to the natural history concerns of the French government and the Museum as these stood in 1815. Intimately related to the government's interest in natural history was the need to reassert the position of France outre-mer. In the immediate postNapoleonic era, the question of overseas colonies was urgent. France's colonial possessions had been significantly reduced during the Napoleonic Wars and in consequence of the Treaty of Vienna. Saint-Domingue had revolted and established its own independence as Haiti. Also lost to France, by the terms of the Peace of 1814, were Isle de France (Mauritius), the Seychelles, and various small islands in the West Indies. France was allowed, however, to keep La Réunion, Martinique, Guadeloupe, Guiana, and her comptoirs in Senegal (Saint-Louis and Gorée), India (Pondichéry, Chandernagor, Mahé, Yanaon, and Karikal), and Saint-Pierre and Miquelon. Reestablishing a productive engagement with these colonial possessions was high on the government's list of priorities.

In the early years of the Restoration, therefore, political and natural history reconnection with the far corners of the globe proceeded to go hand in hand. Naturalists traveled abroad on the same ships that carried French ambassadors or other administrators. When the frigate l'Hermione sailed from France for Rio de Janeiro on 1 April 1816, her passengers included not only the French ambassador, the duc de Luxembourg, but also the botanist Auguste de Saint-Hilaire and the zoologist Pierre-Antoine Delalande (SaintHilaire 1822). A month later, when the king's corvette la Licorne sailed from France for India, she carried not only the administrators 
charged with retaking possession of France's outposts in India, but also the botanist Leschenault de la Tour, who had been appointed "naturalist of the king" and director of the colonial garden at Pondichéry (Leschenault de la Tour 1822). The artists Jacques Milbert and Charles-Alexandre Lesueur likewise traveled overseas in 1816. Milbert traveled with the King's Minister to North America, the Baron Hyde de Neuville. Lesueur traveled not with the support of the French government but rather in the employ of the British geologist William Maclure. By 1817 both Milbert and Lesueur were lobbying for commissions to collect natural history specimens for the Paris Museum.

In this period of renewed overseas activities, when patrons were seeking the help of naturalists and naturalists were seeking the support of patrons, the French Ministries of the Marine and the Interior, in the midst of internal changes of their own, moved to establish closer and more systematic relations with the Museum. The Minister of the Marine in 1817, the Comte de Molé, took the first step. In December 1817 he invited the Museum to prepare a set of generalized instructions for colonial officials, ship commanders, and other travelers who might be in a position to make collections on the $\mathrm{Mu}-$ seum's behalf. Molé had already been asked by Georges Cuvier and the Baron de Férussac, independently of one another, for assistance in securing particular specimens from faraway lands. Molé decided that a general set of instructions would be useful for travelers, his Ministry, and the Museum alike.

The Museum's zoologists, botanists, and mineralogists were more than happy to cooperate with the Minister's request. They collectively composed a 47-page set of instructions detailing the kinds of natural history researches that might usefully be undertaken in the colonies. They described how to collect specimens (both live and dead), how to conserve these specimens, and how to transport them to France. They also took the occasion to identify the particular kinds of plants and animals they wanted from all around the globe. They named Senegal, the Cape of Good Hope, Madagascar, India,
Indonesia, the Mollucas, the Antilles, Cayenne, the neighborhood of the Orinoco River, and New Holland (Australia) as prime regions for exploration. What they wanted above all from Australia, they said, were "Ornithorhyncuses [platypuses] of different species, in quantity if possible, in alcohol [eau de vie]." They also wanted flying phalangers, dasyures, and other didelphes (also preserved in alcohol) ("Instructions" 1818:217).

The professors published their set of instructions in the Memoirs of the Museum and also as a separate booklet in July 1818. They sent 100 copies off to the Minister of the Marine. When the Minister immediately asked for 50 copies more, they sent him an additional 100 (ANF, AJ/15/118, AJ/15/616).

For his part, the Minister of the Interior (then Joseph-Henri-Joachim Lainé) invited the professor administrators of the Museum in November 1818 to think broadly about sending naturalists off on voyages to collect plants and grains that could be brought back and acclimatized either in France or in the colonies. He promised to provide funds for such voyages. More immediately, he was eager to see that means be taken "to transport and to acclimatize in Senegal and at Cayenne [French Guiana] the tree the bark of which is the Quinquina." He reminded the professors that he also wanted them to identify a botanist who could be sent to French Guiana to oversee in that colony the cultivation of useful trees. Famous for the antimalarial properties of its bark, the quinquina or cinchona tree was recognized as a critical resource for Europeans seeking to establish colonies in feverridden parts of the globe (ANF, AJ/15/118, $\mathrm{AJ} / 15 / 616)$.

The Museum's professors René Louiche Desfontaines and André Thouin prepared a detailed document responding to Lainés requests. On 18 November 1818 they presented at the weekly professorial assembly their report on "two propositions of his Excellency the Minister of the Interior, one relative to natural history collections and the other to the introduction of the quinquina trees in the colonies" (ANF, AJ/15/616). They took as their first task "the project of sending naturalists and agriculturists to the two 
hemispheres in order to procure the most interesting productions of the least known countries." They praised the Minister for conceiving of the project, indicating that it was "well worthy of the grandeur of the French government." They then described in detail what would be needed for the project to work. First and foremost, it would require energetic and healthy young men who were knowledgeable about natural history and about collecting, preparing, preserving, and transporting specimens.

The simplest way of getting these naturalists to faraway countries and back again, the professors suggested, was to have them travel on government or commercial ships when these ships sailed to or from the countries in question. The professors noted, however, the disadvantages in tying collecting expeditions too closely to the schedules of the government or commerce. Governmental or commercial schedules often failed to put the collector in the field long enough, or at the best seasons of the year, for collecting specimens. Likewise, plants and animals from warm climates too often ended up being shipped back to Europe at times of the year when the weather was especially hazardous for their health. A better arrangement, the professors indicated, was to establish collecting bases where, over a more or less extended period of time, a naturalist in the field would have the opportunity to build up extensive collections. Ideally, these bases would be in operation long enough to allow for multiple, successive shipments of specimens to be sent off to Europe, thereby insurance against the sorts of losses that were all too common in such endeavors.

In their report, Desfontaines and Thouin went on to review for the Minister the parts of the world where one was most likely to find plants and animals capable of being acclimatized in France. Particularly promising collecting places in the Old World were the shores of the Caspian and Black Seas, Asia Minor, Armenia, Persia, the Caucasus Mountains, and the plateaus of the Tatars and Tibet. These areas, the professors suggested, had provided the original sources of France's present rural economy, and additional useful productions were likely to exist there still. Turning to the New World, Desfontaines and Thouin explained that what was known of the products of North America, South America below the Tropics, Australia, and New Zealand was limited primarily to materials that had been collected near the coasts. They held out the reasonable prospect that the interior of these areas had additional useful organisms yet to offer.

Having promoted at length the idea of sending naturalists to all corners of the globe, the professors turned to the more specific project of naturalizing the cincbona tree in French Guiana. They offered a positive assessment of these prospects, numerous difficulties notwithstanding. Finally, they concluded their report to the Minister by identifying the botanist Antoine Poiteau as the ideal person to oversee the botanical needs of the Guiana colony.

Lainé responded graciously to the professors' report. He thanked them for their insights and information and indicated that he had passed the report on to the Minister of the Marine so that the two of them jointly might help achieve the ends desired, "when favorable circumstances present themselves." His comments also made clear what continued to be the project of most immediate concern: finding the cinchona tree. He asked the Museum to provide specific instructions that could be communicated to administrators in Guiana and Senegal to help them identify the tree in their respective areas (ANF, AJ/15/565).

\section{THE SCHOOL FOR NATURALIST VOYAGERS}

Two months later, in January 1819, there was a new Minister of the Interior, Élie Decazes. Decazes was the former Minister of the Police. He was also a favorite of the king. Along the lines that had begun to be explored by the previous Minister of the Interior, Lainé, and most likely with the encouragement of his own general secretary, the botanist CharlesFrançois Brisseau de Mirbel (who would later become a professor at the Museum himself), 
Decazes moved to establish a more coordinated program for supporting naturalist voyages. Mirbel communicated the Minister's idea to the Museum. The Minister was proposing an "Ecole de jeunes naturalistes destinés à des voyages dans les diverse parties du monde" (school for young naturalists destined for voyages in the diverse parts of the world). The Minister not only proposed the idea of the school, he indicated his willingness to put up the funds for the operation: 20,000 francs per year to support students in the school and naturalist voyagers in the field (ANF, AJ/15/118). The purpose of the school was to train young men so that they could be sent off to the far corners of the globe in search of plants, animals, and minerals useful to France and/or interesting to science. Notwithstanding the history of governmental support for naturalist ventures of various sorts previously, what the Minister was proposing was new. He was offering continuing governmental support for Museum-sponsored naturalist explorations and not merely funds for specific expeditions. Twenty thousand francs, furthermore, was a substantial fund. It represented roughly 7 to $8 \%$ of the total budget of the Museum at that time.

The professors of the Museum, not surprisingly, were enthusiastic about the Minister's idea. They quickly appointed a committee to reflect on the idea and report back to the professorial assembly as a whole. The committee's report, delivered on 10 February 1819 , could not have been more positive. Speaking for the committee, the zoologist Etienne Geoffroy Saint-Hilaire hailed the Minister's plan as "an innovation for our social relations that cannot fail to be welcomed with feelings of a very deep gratitude." Geoffroy did not hesitate to spell out the material implications of the Minister's proposal: it tended toward "nothing less than augmenting, and in a more methodical manner [than ever], the sum of materials without which natural history would be unable to make great progress" (ANF, AJ/15/565).

What was in this for the government? Ministers of the Marine and the Interior wanted to use the Museum's expertise in making colonies like Guiana and Senegal more habitable to French colonists and more profitable to France. Not only did they want to know if the cinchona tree could be grown in Guiana or Senegal, they were also interested in other transplantations as well-and not only of plants. We find, for example, the Minister of the Interior inquiring of the Museum in December 1819 whether it was feasible to transport mongooses from Africa to Martinique as a means of cutting down the snakes and rats that were such a scourge to the colonists there. Significantly enough, in this case, the Minister went on to ask whether a too great multiplication of mongooses in the colonies might not in itself cause certain "inconveniences." The professors cheerfully responded that a problem might arise from the fact that the mongoose was as fond of fowl and other birds as it was of snakes and rats. They believed, however, that the benefits of the mongoose's transplantation were likely to far outweigh any disadvantages. If the mongoose did begin to increase too greatly in number, they noted, it would at any rate be easier to diminish its numbers than the numbers of snakes (ANF, AJ/15/618).

The professors happily advised the government on these and other matters. At the same time, they looked out for their own interests. Once assured of funding for naturalist voyagers, they wanted to have the primary say with respect to where these voyagers would be sent.

The selection of candidates for the new "school for naturalist voyagers" took place in April 1819. A team of professors interviewed twenty-nine applicants, chose six for admission to the school, and identified three for immediate commissions as voyagers. The Museum proposed sending the three to Madagascar, the Philippines, and the shores of the Black Sea. As the Museum explained to the Minister of the Interior, the island of Madagascar was "of all the parts of the world the one where one can hope to collect the most new things." The Philippines, "like all the isles of the archipelago of the Indies," was "rich in singular plants and animals," and it seemed a likely place to find organisms that 
would be "useful to our colonies." As for the shores of the Black Sea, this was an area that naturalists still knew only superficially, and where France could "collect many things useful for our agriculture" (ANF, AJ/15/565).

The new Minister of the Marine (Baron Portal) had other plans. On 2 June 1819 he wrote to the Museum indicating that he had asked the Minister of the Interior to order that two of the naturalist voyagers that the government was proposing to send to diverse countries be specifically directed to French Guiana. "Few explorations of this kind," Portal pontificated, "can be more interesting for science in general than those which would take place in this country; and few countries are as susceptible of offering to the work of naturalists so vast and rich a field." The baron also indicated that he expected this to be done right away. Because the Minister of the Interior would presumably be instructing the Museum to do as he asked, Portal said, he wanted the Museum to prepare instructions as soon as possible for the two voyagers (plus a copy for himself). He also wanted the two voyagers to be able to embark with the new commandant and administrator of Cayenne, who in fact was leaving for Roquefort the next day (ANF, AJ/15/617).

The professors were unwilling to accede to Portal's demands that two of the three new voyagers be dispatched immediately for Guiana. They held their ground with respect to their candidates for Madagascar and the Philippines. They were willing to compromise, however, when it came to the third destination, settling on the Caribbean instead of the Black Sea.

It would be nice to be able to report to readers of Pacific Science that the naturalist sent to the Philippines, a young man named Félix-François Godefroy, made an important contribution to the study of the natural history of the Pacific. Alas, he did not. Some 7 weeks after arriving in Manila, the 22-yearold Godefroy was killed along with some 20 other foreigners by angry natives who believed that the foreigners were responsible for an outbreak of cholera (Thésée 1989:211215). Even shorter was the career in the field of Armand Étienne Maurice Havet, the natu- ralist explorer sent to Madagascar. Just $3 \frac{1}{2}$ weeks after he set foot on the island, the 25year-old Havet succumbed to a violent fever (Marquis 1821-1826). Auguste Plée, the third and the oldest of the three initial representatives of the "school for naturalist voyagers," survived in the Caribbean considerably longer -5 years and 5 months, to be precise. $\mathrm{He}$ died in Martinique in August 1825 at the age of 39 , just as he was making final preparations to return to France. His years as a collector in the Caribbean had not been as productive as either he or the Museum had hoped. Insufficient funding from the Museum and difficulties of maintaining communication with it had hampered his operations (Thésée 1989).

Given these unfortunate results with the above-mentioned voyagers, it would be reassuring if one were able to report that the six candidates who were selected for further training at the Museum's school for naturalists fared any better. Ultimately only one of them, however, Victor Fontanier, completed the training in Paris and went out in the field as a voyager for the Museum, and he proved only marginally successful at best. From the Museum's perspective, Fontanier's shipments from the Levant were all too infrequent, and when they did arrive they were uninspiring.

Yet the project of the school for naturalist voyagers was not a complete disappointment to the Museum. The reason for this is clear. Although the school itself fizzled out, from 1819 until 1832 the Museum received 20,000 francs per year from the Minister of the Interior to support naturalist voyagers. In 1833 the budget was increased. The Museum had never intended to use more than 6000 francs annually for the training of students, and 20,000 francs per year was a great help sustaining naturalists in the field. When necessary, furthermore, the Museum was able to draw upon its voyager funds for other enterprises as well. When, for example, the $\mathrm{Mu}-$ seum decided in 1826 to provide no further funding to Diard, its voyager in the East Indies, this freed funds that were then employed to pay for a research trip to the Alps by the professor of geology, another professor's research trip to Berlin, some financial 
assistance to Plée's widow, and the purchase price of two quaggas, sold to the Museum by the British animal dealer Edward Cross (ANF, AJ/15/567).

Furthermore, even if the first six enrollees in the school were not successes from the Museum's point of view, and even if the $\mathrm{Mu}$ seum never again advertised for candidates for its "school for naturalist voyagers," the Museum in the mid-1820s did use some of its annual funding to train additional young men to be voyagers. It did so for at least two individuals: Victor Jacquemont and Alcide d'Orbigny. Both Jacquemont and d'Orbigny ended up making important collections for the Museum. Jacquemont, unfortunately, became another martyr to science, dying after a few years in India, but d'Orbigny not only lived long enough to tell the tale of his travels, he ultimately became a professor at the Museum himself (Chambord 1998).

THE CREAM OF THE SPECIMENS

The full story of the promotion of French naturalist voyagers during the Restoration remains to be written. Here we have simply sketched out the major motivations and initiatives that were constitutive of the government's and the Museum's efforts. The motives and perspectives of the voyagers or would-be voyagers are subjects for another time. The professors at the Museum as a whole, it bears noting, had actually not logged many miles of their own in voyages to foreign lands. Étienne Geoffroy SaintHilaire had participated in Napoleon's expedition to Egypt, but otherwise the professors' most productive collecting expeditions seem to have been those occasions when, in conjunction with French troops, they collected specimens not through fieldwork but rather by appropriating specimens from the museums or menageries of other countries. The professors had only a limited appreciation of what was involved in being on one's own, collecting in a foreign clime. The voyagers came to recognize this. Claude Gay, for example, having traveled in Chile for the Paris Museum, wrote to Alcide d'Orbigny in 1830 describing how he and a colleague had laughed upon recalling the "good and gullible Parisians who engaged us to zig-zag across this Republic, starting from the North, without neglecting a single mountain." Even if this had been physically possible, the political revolutions of the region made the professors' naive plan inoperable.

What the professors were best able to communicate to the voyagers were not the realities of fieldwork but rather the kinds of animals, plants, and minerals that were most needed for the Museum's collections. As for the practical matters of how best to collect, preserve, and transport specimens, the professors passed on the advice of the late François Péron and the Museum's head taxidermist, the aide-naturaliste Dufresne.

Alcide d'Orbigny, as Darwin scholars will recall, was the naturalist who traveled in South America just before Darwin did. In a letter of October 1832, Darwin wrote from Montevideo to John Stephens Henslow back in England worrying that d'Orbigny might be beating Darwin to the punch in the collection of prize specimens. As Darwin told Henslow, "I am very selfishly afraid that he will get the cream of all the good things, before me" (Darwin 1985:280, Browne 1997:202).

The cream of the specimens was indeed what the professors back at the Museum hoped their voyagers would send them. Indeed within just 3 months of Darwin's penning the above words to Henslow, Étienne Geoffroy Saint-Hilaire used much the same expression at the Museum in Paris. He did so in January 1833 in a fit of pique, accusing his colleague, Henri Marie Ducrotay de Blainville, the new professor of comparative anatomy, of denying him access to particular specimens. What Blainville was doing, Geoffroy complained, was what Blainville's predecessor, Georges Cuvier, had so frequently done when Cuvier was director of the Museum. Cuvier, Geoffroy said, had seen to it that new shipments of specimens were unpacked before his eyes. Then, with the new specimens in front of him, he had "unduly creamed off" ("écrémait induement")— the italics are Geoffroy'sthe particular specimens he needed for writing his great work on comparative anatomy. Geoffroy was furious that this great injustice 
was being allowed to persist at the Museum. As it appeared to him, specimens that should have been available for all to see were being closeted away in obscure storerooms under the control of the new professor of comparative anatomy. Geoffroy's attempts to have this discussed in the professorial assemblies, he told his colleagues, had left him so upset that he was unable to sleep at night, and his health was suffering because of it (ANF, AJ/15/645).

And what were the specimens that Geoffroy in 1833 was so exercised about? Here we finally get to reconnect with the theme of "Pacific science." The specimens in this case were marsupials and monotremes from Australia, collected and transported back to France, preserved in alcohol, by Fortuné Eydoux, surgeon on the French ship Le Favorite. Geoffroy could only presume (or hope), that the collection was highlighted by specimens of the ornithorhyncus, the duckbilled platypus, that marvelous anomaly of animal organization.

The platypus was at this moment one of Geoffroy's special interests. Some years earlier he had advanced the view that the platypus was oviparous, and that it was not a mammal. He argued that platypuses be put with the Echidnae in a class of their own, independent of, and equal in status with, the mammals, birds, reptiles, and fish. In 1833 he was engaged in an ongoing, heated debate with Blainville about the proper classification of the platypus. Blainville took the view that the platypus was indeed a mammal, albeit a bizarre one, with affinities to the marsupials (Burrell 1927). Geoffroy, alluding not to his immediate quarrels with Blainville but rather to contemporary British claims about the platypus, urged his colleagues that he had a long-standing "mission" to pursue the contested question of the nature of the platypus.

The tales of naturalist voyagers collecting specimens for the Paris Museum thus do not simply end with a ship returning safely to France and its cargoes unloaded. Critical steps in a specimen's journey had still to be taken at the Museum itself. At the time Geoffroy Saint-Hilaire lodged his complaint against Blainville, Eydoux's specimens were stored in a cabinet under the main stairway of the galleries of anatomy. They were waiting the time when Eydoux would exercise his right of describing them in print. As Blainville pointed out to his fellow professoradministrators, he did not have the authority to dispose of Eydoux's specimens however he saw fit. They had simply been deposited with him for safekeeping.

Geoffroy's accusations led to the appointment of a committee to investigate whether specimens of great importance to the Museum were being sequestered in the storerooms of the professor of comparative anatomy. The committee, composed of André Marie Constant Duméril and Achille Valenciennes, ended up recommending that the professorial assembly issue an administrative rule about the deployment of specimens (a rule that was supposed to be the practice of the Museum anyway). The rule was that the professor of comparative anatomy should only be allowed to hold specimens in reserve when the species in question were already well represented in the zoology galleries. The debate over the platypus thus turned not only upon the classification of the creature but also upon the whole issue of the control of specimens at the Museum (ANF, AJ/15/645). (For discussion of the platypus in Britain, see Ritvo 1997.)

\section{CABINET NATURALISTS VERSUS NATURALIST VOYAGERS}

Georges Cuvier had always had a keen eye to the collection and control of specimens. He had also left no doubt with respect to his own opinion that laboratory or museum studies were ultimately more illuminating than studies conducted out in the field. Early in the century, in analyzing for the Institut de France Alexander von Humboldt's achievements as a naturalist voyager, Cuvier made it clear that he regarded the work of the cabinet naturalist back in the Museum to be every bit as intellectually challenging and indeed heroic as the work of the naturalist in the field. Cuvier acknowledged that the cabinet naturalist might not be able to see "nature in action," but he felt that the advantages of the cabinet naturalist nonetheless outweighed the advantages of the naturalist in the field. The 
cabinet naturalist, Cuvier argued, was able to pass all of nature's objects in front of him, and study them in depth, and was not subject to the various limitations that the "narrow route" of the naturalist voyager's practice imposed on the voyager (Outram 1984:62-63, 1996).

Two decades later, in reporting on the scientific results of Duperrey's Coquille voyage to the Pacific, Cuvier expressed the same basic view of the superiority of the cabinet naturalist to that of the field naturalist when he spelled out things that the field naturalist should not do: "it is a great error, while on a voyage, to do anything but collect the raw material for study, either by preparing specimens or by drawing what cannot be preserved, or, finally, by writing down the ephemeral details that the specimen does not retain. It is likewise a mistake to waste time with descriptions or in the search for nomenclature, work which will always have to be started afresh once back in the laboratory" (Ollivier 1988:49). From Cuvier's perspective, what mattered was that as many specimens as possible were collected in the field, and that these made it back to his laboratory with their organizational features intact.

In the same year (1825), Georges Cuvier's younger brother Frédéric, in his capacity as superintendent of the menagerie of the $\mathrm{Mu}$ seum of Natural History, expressed a similar view of the nonessentiality of fieldwork. He suggested that menagerie studies might someday render field studies unnecessary. In Frédéric Cuvier's view, when one learned the general faculties and dispositions of a given animal species by studying it in a menagerie, it would no longer be necessary to track the animal down in its native country to see how it lived in the wild. As long as one had a decent appreciation of the environmental conditions of the country, one could predict in advance how the animal would behave there (Cuvier 1825, Burkhardt 1997b).

Humboldt, interestingly enough, in writing his Personal Narrative of his travels, contrasted his own practices as a naturalist traveler not so much with the cabinet naturalists back in European centers as with the naturalists of maritime expeditions who were typically not in a position to explore the interior of the continents they visited. At the same time, though, he made it clear that he was more interested in the "connection of facts" than the collection of specimens. "The discovery of an unknown genus," as he put it, "seemed to me far less interesting than an observation on the geographical relations of the vegetable world, on the migration of the social plants, and the limit of the height which their different tribes attain on the flanks of the Cordilleras" (Humboldt and Bonpland 1818, I:iv). (Be that as it may, Humboldt and his traveling companion, Aimé Bonpland, reported the discovery of some forty new genera of plants from the Torrid Zone.)

We know that Humboldt's travels as a naturalist were an inspiration to later naturalists. D'Orbigny and Darwin were both inspired by Humboldt's writings. Indeed when d'Orbigny was in Paris preparing for his upcoming travels, he made a point of visiting Humboldt to get all the suggestions from the great traveler that he could. We know also, however, that what the professors of the $\mathrm{Mu}$ seum were looking for above all else was not the kind of information Humboldt had collected about physical forces and the distribution of plants. What the professors wanted most of all were more specimens. This is clear from the general instructions they provided for naturalist voyagers. Nonetheless, field observations were encouraged by at least some of the Museum staff. Etienne Geoffroy Saint-Hilaire's son Isidore not only provided d'Orbigny with notes on which species of birds and mammals were especially needed for the Museum's galleries, but also requested in particular that d'Orbigny make observations on these creatures' behavior, "still so little known" (d'Orbigny 1835, I:5).

THE EMPIRE OF NATURE, THE EMPIRE OF THE MUSEUM, AND THE EMPIRE OF FRANCE

How did naturalist voyages intersect with notions of the empire of nature? Certainly one construction of the empire of nature emerged through a comparison of the powers of nature with the powers of humans. This perspective 
was integral, for example, to the "Primary View" of nature that Buffon set forth in Vol. 12 of his Histoire naturelle, générale et particulière in 1764. There Buffon contrasted, on the one hand, nature as it exists without the cultivating hand of humans, and, on the other hand, an improved nature, made more beautiful and productive as humans turned plains into pastures, planted vineyards on hillsides, and so forth. Buffon wrote of "the empire" that humans share or divide with nature. At the same time he noted that humans only enjoy these bounties as the result of the right of conquest, and whenever they cease their industry, "everything returns under Nature's hand; she reclaims her rights" (Buffon 1954:34).

If we thus understand the idea of nature's empire to involve a general idea of the sovereignty of nature's powers, then we can well imagine Humboldt's science to have been particularly conducive to such thinking. Humboldt had demonstrated how climatic and other conditions confined plants to particular regions of the globe (Dettelbach 1996). Significantly enough, furthermore, he had paired the political precariousness of the Spanish colonies of South America with the fragility of their successes in agriculture. In his words, "internal dissensions are chiefly to be dreaded in regions, where civilization is but slightly rooted; and where, from the influence of climate, the forests may soon regain their empire over cleared lands, if their culture be abandoned" (Humboldt and Bonpland 1818, I:xlix-1).

In a period of burgeoning imperial intentions, however, ideas of nature's empire over humans were not preeminent. Significantly, even the Genevan botanist Augustin Pyramus de Candolle, who, following Humboldt, was pioneering the science of plant biogeography at precisely the period in question, was not thinking in terms of the empire of nature so much as he was worrying about how human activities around the globe were disrupting the prior distribution of plant forms. Candolle urged that European botanists hasten to study the flora of faraway lands before intended or accidental plant introductions in those places made it no longer possible to unravel a host of biogeographical problems (Candolle 1820).

For their part, the naturalists at the Paris Museum during the Restoration were disinclined to worry much about the influence of climate or to think in terms of the empire of nature versus the empire of humans. This may have been at least in part because they were not firsthand witnesses to the sorts of resistances that confronted voyagers or especially colonists on location. Back at the Museum, they were disposed to ignore ecological contexts and focus instead on organic forms.

When the professors of the Museum would have been most likely to think at all in terms of nature's empires was when they were called upon by the government to provide advice on specific needs of specific parts of France's empire. Could the cinchona tree be grown in the colonies of French Guiana and Senegal? Could mongooses be brought from Africa to control snakes and rats in Martinique? These, as I have indicated, were projects on which the naturalists of the Museum willingly lent their expertise. But they were also projects where the naturalists remained confident of humanity's empire over nature. They themselves only indirectly experienced the occasional failures of European empire. They did not have the firsthand experiences of the colonists or, for that matter, their own naturalist voyagers. They were not with Havet in Madagascar, for example, when he was vomiting up black blood and dying of fever. Nor were they with Godefroy in the Philippines when angry natives hacked him to death. Back at the Museum, the professors were inclined to downplay political and ecological contexts and focus instead on questions of organic form.

The issues that exercised the professors the most-the issues of the sort that caused Geoffroy sleepless nights-pertained to the collection of specimens and their subsequent control and analysis back at the Museum. To repeat what Geoffroy said about the school for naturalist voyagers, its chief feature attraction to the Museum was that it promised to increase in a regular fashion "the sum of materials without which natural history would be unable to make great progress." 
The French government conceived of the school for naturalists with the expectation that discoveries by naturalists would be of appreciable benefit to the health and the wealth of the colonies. The professors of the Museum, by contrast, viewed the school above all as a means of ensuring supplies of specimens upon which their sciences depended. They would identify, order, and display these specimens in the galleries of the great metropolitan institution that was the Paris Museum of Natural History. From the standpoint of their scientific practice, nature's empire was simply the sum total of her products. To the cabinet naturalist, in other words, as the collections of the Paris Museum swelled, the museum and the empire of nature became one and the same.

\section{ACKNOWLEDGMENTS}

I thank Roy MacLeod for what I trust will be continuing discussion of different meanings of "the empire of nature."

\section{Literature Cited}

\section{Manuscripts}

The details of the story of the school for naturalist voyagers and the initiatives that led up to the founding of the school are to be found in manuscript documents of the Muséum d'Histoire Naturelle conserved in Paris at the Archives Nationales de France (cited in the text as ANF). Most helpful here are the two series "Minutes des Procès Verbaux des Assemblées de professeurs, et pièces annexes" (AJ/15/577-678) and "Procès Verbaux des Assemblées des professeurs" (AJ/15/ 96-142) and a number of cartons devoted exclusively or in part to naturalist voyagers (especially AJ/15/565).

\section{Printed Sources}

Bonnemains, Jacqueline. 1988. The history of the Lesueur collection of the Museum d'histoire naturelle du Havre. Pages 65-68 in Jacquelin Bonnemains, Elliott Forsyth, and Bernard Smith, eds. Baudin in Aus- tralian waters: The artwork of the French Voyage of Discovery to the Southern Lands 1800-1804. Oxford University Press, Melbourne.

Bonnemains, Jacquelin, Elliott Forsyth, and Bernard Smith, eds. 1988. Baudin in Australian waters: The artwork of the French Voyage of Discovery to the Southern Lands 1800-1804. Oxford University Press, Melbourne.

Bourguet, M.-N. 1997. La Collecte du monde: Voyage et histoire naturelle (fin XVIlème siècle-début XIXème siècle). Pages 163-196 in C. Blanckaert, C. Cohen, P. Corsi, and J.-L. Fischer, eds. Le Muséum au premier siècle de son histoire. Muséum National d'Histoire Naturelle, Archives, Paris.

Brockway, Lucile H. 1979. Science and colonial expansion: The role of the British Royal Botanic Gardens. Academic Press, New York.

Browne, Janet. 1997. Une science impérialiste: L'histoire naturelle britannique et les voyages d'exploration de Banks à Darwin. Pages 197-210 in C. Blanckaert, C. Cohen, P. Corsi, and J.-L. Fischer, eds. Le Muséum au premier siècle de son histoire. Muséum National d'Histoire $\mathrm{Na}$ turelle, Archives, Paris.

Buffon, Georges Louis Leclerc, Comte de. 1954. Histoire Naturelle. Première Vue! Pages 30-35 in Jean Piveteau, ed. Oeuvres philosophiques de Buffon. Presses Universitaires de France, Paris.

Burkhardt, Richard W., Jr. 1997a. Unpacking Baudin: Models of scientific practice in the age of Lamarck. Pages 497-514 in Goulven Laurent, ed. Jean-Baptiste Lamarck, 1744-1829. Éditions du CTHS, Paris.

1997b. La ménagerie et la vie du Muséum. Pages 481-508 in C. Blanckaert, C. Cohen, P. Corsi, and J.-L. Fischer, eds. Le Muséum au premier siècle de son histoire. Muséum National d'Histoire $\mathrm{Na}-$ turelle, Archives, Paris.

Burrell, Harry. 1927. The platypus: Its discovery, zoological position, form and characteristics, habits, life history, etc. Angus \& Robertson, Sydney. 
Candolle, Augustin Pyramus de. 1820. Géographie botanique. Pages 359-422 in Dictionnaire des sciences naturelles, 18. Levrault, Strasbourg.

Chambord, Antoine. 1998. Alcide Dessalines d'Orbigny. De l'école de la nature à la politique des voyages sous la Restauration. Pages 232-257 in Danielle Lecoq and Antoine Chambord, eds. Terre à découvrir, terres à parcourir. L'Harmattan, Paris.

Collini, S., and A. Vannoni. 1997. Introduzione. Pages 15-48 in S. Collini and A. Vannoni, eds. Le istruzioni scientifiche per i viaggiatori (XVII-XIX secolo). Edizioni Polistampa, Firenze.

Cuvier, Frédéric. 1825. Essai sur la domesticité des mammifères. Mem. Mus. Hist. Nat. 13:406-455.

Darwin, Charles. 1985. The correspondence of Charles Darwin. Vol. 1, 1821-1836. F. Burkhardt and S. Smith, eds. Cambridge University Press, Cambridge.

Dettelbach, Michael. 1996. Global physics and aesthetic empire: Humboldt's physical portrait of the tropics. Pages 258-292 in David Philip Miller and Peter Hanns Reill, eds. Visions of empire: Voyages, botany, and representations of nature. Cambridge University Press, Cambridge.

D’Orbigny, Alcide. 1835-1847. Voyage dans l'Amérique méridionale. 9 vols. Bertrand, Paris, and Levrault, Strasbourg.

Drayton, Richard. 2000. Nature's government: Science, Imperial Britain, and the 'improvement' of the world. Yale University Press, New Haven.

Dunmore, John. 1969. French explorers in the Pacific. 2 vols. Oxford University Press, Oxford.

Geoffroy Saint-Hilaire, Étienne. 1825. Rapport verbal fait à l'Académie royale des Sciences sur la partie zoologique du Voyage autour du Monde, de M. le capitaine de vaisseau, Louis de Freycinet. Ann. Sci. Nat. 5:341-352.

Grove, Richard. 1995. Green imperialism: Colonial expansion, tropical island edens and the origins of environmentalism, 1600-1860. Cambridge University Press, Cambridge.

Horner, Frank. 1988. The Baudin expedition to Australia 1800-1804. Pages 1-17 in Jacquelin Bonnemains, Elliott Forsyth, and Bernard Smith, eds. Baudin in Australian waters: The artwork of the French Voyage of Discovery to the Southern Lands 1800-1804. Oxford University Press, Melbourne.

Humboldt, Alexander von, and Aimé Bonpland. 1818. Personal narrative of travels to the equinoctial regions of the new continent, during the years 1799-1804. 2 vols. Longman etc., London.

Instructions sur les recherches qui pourraient être faites dans les colonies, sur les objets qu'il serait possible d'y recueillir et sur la manière de les conserver et de les transporter. 1818. Mem. Mus. Hist. Nat. 4:193239.

Jussieu, A.-L. 1804. Notice sur l'expédition à la Nouvelle-Hollande, entreprise pour des recherches de géographie et d'histoire naturelle. Ann. Mus. Hist. Nat. 4:1-11.

Laissus, Yves. 1981. Les voyageurs naturalistes du Jardin du Roi et du Muséum d'histoire naturelle: Essai de portraitrobot. Rev. Hist. Sci. 34:259-317.

Latour, Bruno. 1987. Science in action. Open University Press, Milton Keynes, U.K.

Leschenault de la Tour, [Jean-BaptisteLouis-Claude-Théodore]. 1822. Relation abrégé d'un voyage aux indes orientale. Mem. Mus. Hist. Nat. 9:245-274.

MacLeod, Roy. 1993. Passages in imperial science: From empire to commonwealth. J. World Hist. 4:117-150.

- ed. 2000. Nature and empire: Science and the colonial enterprise. Osiris 15.

MacLeod, Roy, and Milton Lewis, eds. 1988. Disease, medicine, and empire: Perspectives on Western medicine and the experience of European expansion. Routledge, London.

MacLeod, Roy, and Philip Rehbock, eds. 1988. Nature in its greatest extent: Western science in the Pacific. University of Hawai'i Press, Honolulu.

—. 1994. Darwin's laboratory: Evolutionary theory and natural history in the Pacific. University of Hawai'i Press, Honolulu. 
Marquis. 1821-1826. Havet (Armand Étienne Maurice). In A. J. Mahul, Annuaire nécrologique. 6 vols. Baudouin frères, Paris.

McClellan, James E., III. 1992. Colonialism and science: Saint Domingue in the old regime. Johns Hopkins University Press, Baltimore.

McKay, David. 1985. In the wake of Cook: Exploration, science \& empire, 17801801. Croom Helm, London.

Miller, David Philip, and Peter Hanns Reill, eds. 1996. Visions of empire: Voyages, botany, and representations of nature. Cambridge University Press, Cambridge.

Ollivier, Isabel. 1988. Pierre-Adolphe Lesson, surgeon-naturalist: A misfit in a successful system. Pages 45-64 in Roy MacLeod and Philip F. Rehbock, eds. Nature in its greatest extent: Western science in the Pacific. University of Hawai'i Press, Honolulu.

Osborne, Michael A. 1994. Nature, the exotic, and the science of French colonialism. Indiana University Press, Bloomington.

Outram, Dorinda. 1984. Georges Cuvier:
Vocation, science, and authority in postrevolutionary France. Manchester University Press, Manchester.

1996. New spaces in natural history. Pages 249-265 in N. Jardine, J. A. Secord, and E. C. Spary, eds. Cultures of natural history. Cambridge University Press, Cambridge.

Reingold, Nathan, and Marc Rothenberg, eds. 1987. Scientific colonialism: A crosscultural comparison. Smithsonian Institution Press, Washington, D.C.

Ritvo, Harriet. 1997. The platypus and the mermaid and other figments of the classifying imagination. Harvard University Press, Cambridge, Massachusetts.

Saint-Hilaire, Auguste de. 1822. Aperçu d'un voyage dans l'intérieur du Brésil, la province Cisplatine et les missions dites du Paraguay. Mem. Mus. Hist. Nat. 9:307380.

Thésée, Françoise. 1989. Auguste Plée1786/1825: Un voyageur naturaliste, ses travaux et ses tribulations aux Antilles, au Canade, en Colombie. Éditions Caribéennes, Paris. 